\title{
Fractal Analysis of Temporomandibular Joint Trabecular Bone Structure in Patients with Rheumatoid Arthritis on Cone Beam Computed Tomography Images
}

\section{Konik Işınlı Bilgisayarlı Tomografi Görüntülerinde Romatoid Artrit Hastalarının Tempromandibular Eklemdeki Trabeküler Kemik Yapısının Fraktal Analizi}

\author{
(D) Selin Yeşiltepe ${ }^{1}$, (D) Ahmet Berhan Yılmaz ${ }^{2}$, (D) Elif Kurtuldu², (D) Irfan Sarıca ${ }^{3}$ \\ ${ }^{1}$ Aydın Adnan Menderes University Faculty of Dentistry, Department of Oral and Maxillofacial Radiology, Aydın , Turkey \\ ${ }^{2}$ Atatürk University Faculty of Dentistry, Department of Oral and Maxillofacial Radiology, Erzurum, Turkey \\ ${ }^{3}$ Bezmialem Vakıf University Faculty of Dentistry, Department of Oral and Maxillofacial Radiology, İstanbul, Turkey
}

Keywords

Rheumatoid arthritis, trabecular bone, cone beam computed tomography, fractal analysis

Anahtar Kelimeler

Romatoid artrit, trabeküler kemik, konik ışınlı bilgisayarlı tomografi, fraktal analiz

Received/Geliş Tarihi : 10.07.2017

Accepted/Kabul Tarihi : 09.04.2018

doi:10.4274/meandros.36035

Address for Correspondence/Yazışma Adresi: İrfan Sarıca MD,

Bezmialem Vakıf University Faculty

of Dentistry, Department of Oral and

Maxillofacial Radiology, İstanbul, Turkey

Phone : +90 5413394409

E-mail : rfnsrc@gmail.com

ORCID ID: orcid.org/0000-0003-1038-8275

(C) Meandros Medical and Dental Journal, Published by Galenos Publishing House.

This is article distributed under the terms of the

Creative Commons Attribution NonCommercial 4.0

International Licence (CC BY-NC 4.0).

\begin{abstract}
Objective: The aim of this study was to evaluate the fractal dimension (FD) analysis in the temporomandibular joint for changes in trabecular bone structure on cone beam computed tomography (CBCT) images of patients with rheumatoid arthritis (RA).

Materials and Methods: In this study 17 female RA patients and 16 healthy female individuals who were underwent CBCT imaging with for diagnostic purposes such as pathologic lesion and implant treatment planning, were evaluated and fractal analysis was performed using Image J (National Institutes of Health, Bethesda, MD) program with box-counting method. The results were analysed using Student t-test with SPSS 20.0 (SPSS, Chicago; IL, USA) software program.

Results: According to the results, FD values of RA patients have wide range (for right side minimum: 0.919, maximum: 1.169 and for left side minimum: 0.958, maximum: 1.155). Statistical analysis of FD values showed significance between RA patients and the healthy individuals for both right/left sides (for the right side, the RA patients had a mean FD of 1.055, and the control group had a mean FD of 1.113; for the left side, the RA patients had a mean FD of 1.060, and the control group had a mean FD of 1.111) $(p<0.05)$. There was no significant different between FD values of right and left side of mandibular condyle.

Conclusion: RA patients have lower FD values than healthy individuals for each side which means bone complexity of RA patients are less. The results recommend that FD is a promising tool for detection of bone-related bone changes.
\end{abstract}

Öz

Amaç: Bu çalışmanın amacı, romatoid artritli (RA) hastaların konik ışınlı bilgisayarlı tomografi (KIBT) görüntüleri üzerinde temporomandibular eklemin trabeküler kemik yapısındaki değiş̧iklikleri fraktal boyut (FB) analizi ile değerlendirmektir.

Gereç ve Yöntemler: Bu çalışmada, patolojik lezyon veya implant tedavi planlaması gibi tanı amacıyla KIBT görüntülemesi yapılan 17 kadın RA hastası ve 16 sağlıklı kadın birey değerlendirildi ve Image J (National Institutes of Health, Bethesda, MD) 
programı kullanılarak kutu sayma yöntemi ile fraktal analiz yapıldı. Sonuçlar SPSS 20.0 (SPSS, Chicago, IL, ABD) programı ile Student t-testi kullanılarak değerlendirildi.

Bulgular: RA hastalarının FB değerleri sağda minimum: 0,919, maksimum: 1,169 ve solda minimum: 0,958, maksimum: 1,155 olarak ölçüldü. FB değerlerinin istatistiksel analizi, sağ ve sol taraflar için RA hastaları ile sağlıklı bireyler arasında istatistiksel olarak anlamlı farklılık gösterdi (sağ taraf için RA hastalarının FB ortalaması 1,055, kontrol grubunun FB ortalaması 1,113, sol taraf için ise RA hastalarının FB ortalaması 1,060, kontrol grubunun FB ortalaması 1,111'dir) $(p<0,05)$. Mandibuler kondilin sağ ve sol tarafı arasında ise FB değerleri istatistiksel olarak anlamlı fark göstermemektedir.

Sonuç: RA hastalarının her bir taraf için sağlıklı kişilere göre FB değerleri daha düşüktür, bu da RA hastalarının kemik yoğunluğunun daha az olduğu anlamına gelir. Sonuçlar FB'nin RA ile ilişkili kemik değişikliklerinin saptanmasında umut verici bir araç olduğunu düşündürmektedir.

\section{Introduction}

Rheumatoid arthritis (RA) is a systemic, chronic, autoimmune, inflammatory and erosive joint disease (1). Although RA usually affects the metacarpophalangeal, proximal interphalangeal and metatarsophalangeal joints, it can also affect other joints. Temporomandibular joint (TMJ) involvement is usually seen in advanced cases (2).

Fundamental changes in the process of bone remodeling potentially lead to changes in the structural and mechanical properties of bones (1). Rheumatic inflammation reduces the bone strength and toughness of the periarticular bone by disrupting bone quality and bone mass. In RA, periarticular osteoporosis is the first morphological sign associated with the disease and is seen before erosion and narrowing of the joint space (3).

Patients with RA are at risk for secondary osteoporosis. A change in bone architecture provides information for the diagnosis of osteoporosis and a possible fracture risk (4-6).

Because the trabecular bone has a higher metabolic activity than the cortex of the alveolar bone, it is more suitable for use in evaluating changes (7). The fractal dimension (FD) of the trabecular bone structure has been proven to have a significant correlation with the physical properties of the bone (8).

FD analysis is a statistical tissue analysis used to describe complex shapes and structural patterns based on fractal mathematics (9). A small FD value indicates a larger number of gaps in the bone, while a greater FD value indicates a smaller number of voids in the bone $(4,10)$. It has been shown that an FD increases both after the experimental demineralization of bone and after changes in bone density due to age or disease $(11,12)$.

Various studies have been conducted to apply different methods of analyzing bone structure with panoramic radiography (13-15). Only a limited number of studies have assessed bone structure using cone beam computerized tomography (CBCT) (16-18). While the detailed trabecular structure can not be achieved due to low resolution, the texture pattern in CBCT can still provide discriminative data to separate different trabecular patterns (16). It has been shown that fractal analysis can be applied to CBCT images for evaluation of bone quality (18). $\mathrm{CBCT}$ is used in dentistry in many different diagnoses such as assessing the bone quality before implant placement or identifying and following a variety of bone lesion types. Clinical applications in the field of dentomaxillofacial radiology have gained importance and become widespread (19).

In this study, CBCT data and the fractal analysis method were used to evaluate and compare the trabecular bone structure changes in condyle heads of patients in the RA group with those of the control group.

\section{Materials and Methods}

\section{Subjects}

In the present study, 17 female RA patients and 16 healthy female individuals who underwent CBCT imaging for various diagnostic purposes, such as pathologic lesion and implant treatment planning, were evaluated retrospectively. None of the study participants had any congenital TMJ disorder or surgical treatment for TMJ. The RA patients ranged in age from 20-63 years (mean of 44.4 years), and the healthy individuals ranged in age from 26-64 years (mean of 42 years). The control and RA patient groups were matched according to age and gender criteria. The CBCT examinations were performed at Atatürk University Faculty of Dentistry, Department of Dentomaxillofacial Radiology. The RA patients did not have any systemic disease other than RA, and 
the control group did not have any type of systemic disease.

\section{Cone Beam Computerized Tomography Data}

CBCT images were obtained by using the NewTom 3G (Quantitative Radiology, Verona, Italy) which has a maximum output of $110 \mathrm{kV}$ and $15 \mathrm{~mA}$, a $0.16-\mathrm{mm}$ voxel size, and an approximate $5.4 \mathrm{~s}$ exposure time as scanner parameters. In the first instance, the TMJ was examined by viewing $0.5 \mathrm{~mm}$ axial slices; the coronal slices were selected from the axial views on which condylar process is the widest in mediolateral dimension. The coronal slices were taken in $0.3 \mathrm{~mm}$ thickness and parallel to the long axis of the condylar process on the selected axial image. All CBCT images were evaluated by a single observer.

\section{Fractal Dimension Analysis}

All the condyle slices were saved as JPEG images via the NNT Viewer software program. The regions of interest (ROIs) were selected as $20 \times 20$ pixels within each image with the use of Photoshop CS6 13.08 .0 (Adobe Inc., San Jose, CA). The ROIs, located in the middle of the coronal TMJ slice (Figure 1), were cropped by using Adobe Photoshop and saved as JPEG images. The images were then transferred to the Image J (IJ) version 1.51 program (National Institutes of Health, Bethesda, MD @; https://imagej.nih.gov/ $\mathrm{ij} /$ download.html) (20) in order to calculate the FDs. In this study, the images were converted to binary images by using the method created by White and Rudolph (21). The ROIs were duplicated and blurred by using a Gaussian filter with a diameter of 35 pixels. The blurring process aims to eliminate all fine- and medium-scale variations in image brightness. The blurred images were extracted from the original ROIs. To reflect each of the image's variations, such as trabecular bone structure and marrow spaces, 128 value was added to the obtained images at all pixel locations. The results were converted to binary with thresholding and a brightness value of 128 . The binary images were eroded and dilated on time to minimize the noise. The final images were obtained after inverting and skeletonizing the binary images. On the skeletal binary images, the skeletal structure represents the bone pattern and the non-skeletal structure depicts the bone marrow (Figure 2). The FDs of the skeletonized images were calculated by using the box counting tool on Image J 1.51 program. The images were analyzed by covering it with a square grid of equally sized tiles. The widths of the square boxes were $2,3,4,6,8,12,16,32$, and 64 pixels. The number of the counted squares was plotted against the number of squares in the double logarithmic scale, and the FDs were calculated from the inclination of the line fitted on the data points (Figure 3 ).
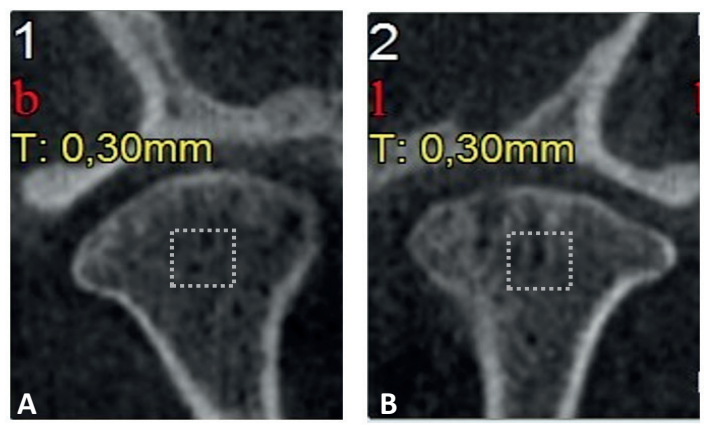

Figure 1. Coronal image of temporomandibular joint slice thickness is $0.3 \mathrm{~mm}$. Regions of interest were taken from the mostly middle of the condyle and suitable place which has no cortical bone. A) right side, B) left side

A

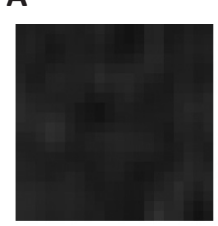

B
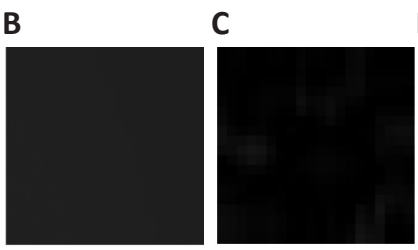

D

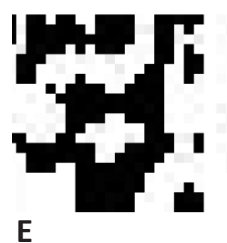

E

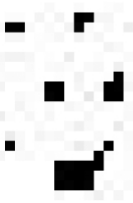

$\mathbf{F}$

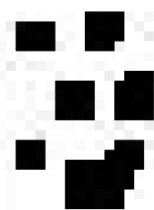

G

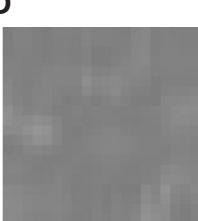

Figure 2. Image processing steps. A) Regions of interest $20 \times 20$ pixel, B) gaussian blurred image (diameter 35 pixel), C) image $B$ was substracted from image, A D) 128 added, E) binary image, F) eroded image, G) dilated image, $\mathrm{H}$ ) skeletonized

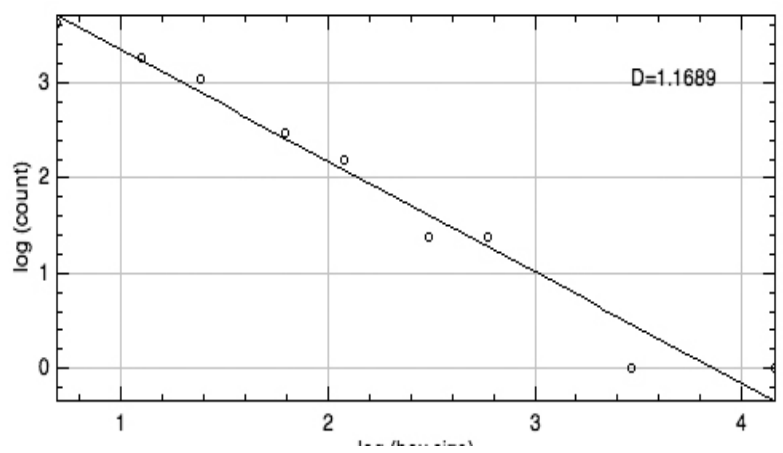

Figure 3. Fractal dimension calculation of the images with box counting method 


\section{Statistical Analysis}

The FD values for both the RA patients and the control group are listed in Table 1. Statistical analyses were carried out using the SPSS 20.0 (SPSS, Chicago, IL) software program. The independent Samples t-test was used to determine the difference between FD values of the healthy individuals and the RA patients. Significance was defined as $p \leq 0.05$.

\section{Results}

Table 1 presents the FD values of every participant and Table 2 presents the mean values and standard deviations. The results indicated that RA patients had lower FDs than the healthy individuals for both the right and left sides of the condyle head, which means that RA patients had a lesser bone complexity. The FD values of the RA patients showed a wide range (for the right side, a minimum of 0.919 and a maximum of 1.169; for the left side, a minimum of 0.958 and a maximum of 1.155). A statistical analysis of the FD values showed significance between the RA patients and the healthy individuals for both right and left sides (for the right side, the RA patients had a mean FD of 1.068, and the control group had a mean FD of 1.113; for the left side, the RA patients had a mean FD of 1.060, and the control group had a mean FD of 1.111) $(p<0.05)$. The FD values of the trabecular bone structure support the hypothesis of this study which is there's a significant difference between the individual trabecular bone complexity of female RA patients and females without RA.

\section{Table 1. Presents fractal dimension values of right and left temporomandibular joints regions of interest}

\begin{tabular}{|c|c|c|c|}
\hline \multicolumn{2}{|l|}{ TMJ right side } & \multicolumn{2}{|l|}{ TMJ left side } \\
\hline RA patients FD & Healhty individuals FD & RA patients FD & Healhty individuals FD \\
\hline 1.063 & 1.223 & 1.036 & 1.112 \\
\hline 1.083 & 1.097 & 1.084 & 1.201 \\
\hline 1.117 & 1.140 & 1.049 & 1.165 \\
\hline 1.041 & 1.139 & 1.074 & 1.028 \\
\hline 1.074 & 1.051 & 0.958 & 1.047 \\
\hline 1.077 & 1.142 & 1.001 & 1.112 \\
\hline 1.073 & 1.142 & 1.045 & 1.162 \\
\hline 0.976 & 1.114 & 1.155 & 1.148 \\
\hline 1.070 & 1.173 & 1.119 & 1.141 \\
\hline 1.169 & 1.132 & 1.015 & 1.074 \\
\hline 1.027 & 1.130 & 0.967 & 1.169 \\
\hline 1.122 & 1.019 & 1.087 & 1.148 \\
\hline 1.143 & 1.151 & 1.085 & 1.186 \\
\hline 1.077 & 1.028 & 1.033 & 0.955 \\
\hline 1.077 & 1.031 & 1.069 & 1.010 \\
\hline 0.919 & 1.109 & 1.135 & 1.128 \\
\hline 1.050 & - & 1.112 & - \\
\hline
\end{tabular}




\begin{tabular}{|c|c|c|c|c|c|}
\hline Group & $n$ & Mean & Standard deviation & Standard error of the mean & p (2-tailed) \\
\hline \multicolumn{6}{|c|}{ TMJ right side } \\
\hline 1 & 17 & 1.06812 & 0.058683 & \begin{tabular}{|l|}
0.014233 \\
\end{tabular} & \multirow[b]{2}{*}{0.030} \\
\hline 2 & 16 & 1.11381 & 0.056434 & 0.014109 & \\
\hline \multicolumn{6}{|c|}{ TMJ left side } \\
\hline 1 & 17 & 1.06024 & 0.055481 & 0.013456 & \multirow[b]{2}{*}{0.026} \\
\hline 2 & 16 & 1.11163 & 0.069962 & 0.017490 & \\
\hline
\end{tabular}

\section{Discussion}

RA is characterized by synovial membrane, cartilage and subchondral bone inflammation, and injury of joints that cause joint space and loss of function. Although radiographic changes occur in $60 \%$ of RA patients, these changes are not observable in the early stages of the disease (22). Periarticular osteopenia is an early and diffuse characteristic of RA and may be the first morphological change associated with the disease. At the same time, patients with RA are at risk for secondary osteoporosis (23).

Various studies have shown that fractal analysis, a quantitative tool for examining the morphology of complex structures. It can show the changes of trabecular bone structure in some diseases, such as sickle cell anemia, osteoporosis and hyperparathyroidism. According to these studies, the FD values of trabecular bone were related with differences between patient and healthy groups with respect to changes in trabecular bone architecture and bone density $(21,24-26)$.

Alman et al. (27) and Demirbas et al. (25) reported that FD analysis was performed on spongeous bone of the second premolar and first molar teeth. Because trabecular bone has a higher metabolic activity than cortical bone, it determines bone structure changes (28). In this study, we also performed fractal analysis on the trabecular bone at the condyle head in the TMJ.

Alveolar bone shows changes in its internal structure, with a physiological adaptation capacity to accommodate the forces to which it is exposed. It is thought that the anisotropic feature of the trabecular bone and changes in the trabecular thickness cause different results in FD studies $(5,25,29,30)$.

Although the literature states that as the FD increases, the complexity of the structure increases, there is no consensus on this subject. Differing results of FD studies are related to anatomical variations, the use of various techniques in obtaining FDs, and the examination of different regions in alveolar bone. It is also important to understand how the disease affects bone quality and how different sections of the body are affected by this condition. Additionally, it is critical to determine the criteria for choosing the $\mathrm{ROI}$ and the course of obtaining two-dimensional images $(11,25,31)$ In our study, CBCT images were obtained with fixed exposure parameters by selecting standardized ROIs within the cortical borders of both mandibular condyles.

In contrast to the results of our study, some researchers, such as Ruttimann et al. (32) and Hua et al. (18) reported that FD is increased in some patients with diseases that cause osteoporotic effects on bone structure. However, Demirbas et al. (25), Southard et al. (10), Updike and Nowzari (31) and Ergun et al. (5) have reported decreased FD values. In this study, it was found that the right and left condyle head FD measurements in RA patients were significantly lower than those of the control group.

In their study of osteoporosis detection by fractal analysis of dental radiographs, Doyle et al. (33) reported that mandibular FD measurements in postmenopausal women were higher than those of premenopausal women.

Southard et al. (10) compared their own results with the results of Ruttimann et al. (32) and argued that the differences in the results may have been caused by the different analysis methods used. While there are many different approaches to the fractal analysis, the box-count is the most preferred method. $(5,31)$ Therefore this method was chosen for this study. 
Various studies have been conducted to apply several methods to analyze bone structure with panoramic radiography $(9,34)$. Conventional radiography has disadvantages, such as limited sensitivity, in detecting early joint space narrowing and periarticular osteoporosis (35). Additionally, some studies have assessed the correlation between bone parameters obtained by СBCT or high-resolution micro-CT scans (36-40). CBCT allows direct visualization of the trabecular structure by eliminating superpositions, and the condyle head can be examined in three-dimensions. Given the clinical practice, previous studies have shown that the use of FDs in CBCT is giving promising results $(17,41)$.

The preliminary results of Hua et al.'s (18) study showed that measuring bone area and fractal analysis had some potential for assessing bone quality in CBCT images. The results of Ling et al.'s (16) study support the use of CBCT for advanced trabecular analysis.

\section{Study Limitations}

The present retrospective pilot study has some limitations. Firstly, although CBCT provides superior diagnostic imaging for TMJ, it involves higher radiation exposure compared with conventional radiography and it is not routinely used in every patient in dentistry. Nevertheless, with consideration the disadvantage of $\mathrm{CBCT}$, alternative studies can be carried out using a large number of patient data. Another limitation is that this study was carried out by CBCT images of RA patients that were stored at the Oral and Maxillofacial Radiology Department at the Ataturk University and the number of participant was limited.

\section{Conclusion}

In our study, structure of the trabecular bone in the condyle head was evaluated in RA and control group patients was evaluated by fractal analysis with CBCT data. The patients with RA included in our study were not admitted to our clinic with joint complaints. CBCT was required for various reasons. The results of this study demonstrate that osteoporosis-related changes in the condyle heads of RA patients can be identified by FD analysis on CBCT images.

\section{Ethics}

Ethical Committee Approval: Retrospective study. Informed Consent: Retrospective study.

Peer-review: Externally peer-reviewed.

\section{Authorship Contributions}

Concept:S.Y., E.K., I.S., Design: A.B.Y., Data Collection or Processing: E.K., S.Y., Analysis or Interpretation: S.Y., E.K., Literature Search: S.Y., Writing: S.Y., E.K., I.S.

Conflict of Interest: No conflict of interest was declared by the authors.

Financial Disclosure: The authors declared that this study received no financial support.

\section{References}

1. Paget SA, Gibofsky A, Beary JF. Romatoloji ve klinik ortopedi el kitabı. 4 th ed. İstanbul: Nobel Tıp Kitapevleri; 2004.

2. Akil M, Veerapen K. Rheumatoid arthritis: clinical features and diagnosis. In: MLS, editor. ABC of rheumatology. 3rd ed. London: BMJ Publishing; 2004. p. 50-60.

3. Mikuls TR. Co-morbidity in rheumatoid arthritis. Best Pract Res Clin Rheumatol 2003; 17: 729-52.

4. Sanchez-Molina D, Velazquez-Ameijide J, Quintana V, ArreguiDalmases C, Crandall JR, et al. Fractal dimension and mechanical properties of human cortical bone. Med Eng Phys 2013; 35: 57682.

5. Ergun S, Saracoglu A, Guneri P, Ozpinar B. Application of fractal analysis in hyperparathyroidism. Dentomaxillofac Radiol 2009; 38: 281-8.

6. Pothuaud L, Benhamou CL, Porion P, Lespessailles E, Harba R, Levitz $P$. Fractal dimension of trabecular bone projection texture is related to three-dimensional microarchitecture. J Bone Miner Res 2000; 15: 691-9.

7. Fazzalari NL, Parkinson IH. Fractal properties of subchondral cancellous bone in severe osteoarthritis of the hip. J Bone Miner Res 1997; 12: 632-40.

8. Jolley L, Majumdar S, Kapila S. Technical factors in fractal analysis of periapical radiographs. Dentomaxillofac Radiol 2006; 35: 3937.

9. Bollen AM, Taguchi A, Hujoel PP, Hollender LG. Fractal dimension on dental radiographs. Dentomaxillofac Radiol 2001; 30: 270-5.

10. Southard TE, Southard KA, Jakobsen JR, Hillis SL, Najim CA. Fractal dimension in radiographic analysis of alveolar process bone. Oral Surg Oral Med Oral Pathol Oral Radiol Endod. 1996; 82: 569-76.

11. Tosoni GM, Lurie AG, Cowan AE, Burleson JA. Pixel intensity and fractal analyses: detecting osteoporosis in perimenopausal and postmenopausal women by using digital panoramic images. Oral Surg Oral Med Oral Pathol Oral Radiol Endod 2006; 102: 235-41.

12. Otis LL, Hong JS, Tuncay OC. Bone structure effect on root resorption. Orthod Craniofac Res 2004; 7: 165-77.

13. Hastar E, Yilmaz HH, Orhan $H$. Evaluation of mental index, mandibular cortical index and panoramic mandibular index on dental panoramic radiographs in the elderly. Eur J Dent 2011; 5: 60-7.

14. Ferreira Leite A, de Souza Figueiredo PT, Ramos Barra F, Santos de Melo N, de Paula AP. Relationships between mandibular cortical indexes, bone mineral density, and osteoporotic fractures in 
Brazilian men over 60 years old. Oral Surg Oral Med Oral Pathol Oral Radiol Endod 2011; 112: 648-56.

15. Dutra V, Devlin H, Susin C, Yang J, Horner K, Fernandes AR. Mandibular morphological changes in low bone mass edentulous females: evaluation of panoramic radiographs. Oral Surg Oral Med Oral Pathol Oral Radiol Endod 2006; 102: 663-8.

16. Ling $H$, Yang $X$, Li $P$, Megalooikonomou V, Xu Y, Yang J. Cross gender-age trabecular texture analysis in cone beam CT. Dentomaxillofac Radiol 2014; 43: 20130324.

17. Torres SR, Chen CS, Leroux BG, Lee PP, Hollender LG, Schubert MM. Fractal dimension evaluation of cone beam computed tomography in patients with bisphosphonate-associated osteonecrosis. Dentomaxillofac Radiol 2011; 40: 501-5.

18. Hua Y, Nackaerts O, Duyck J, Maes F, Jacobs R. Bone quality assessment based on cone beam computed tomography imaging. Clin Oral Implants Res 2009; 20: 767-71.

19. Scarfe WC, Farman AG, Sukovic P. Clinical applications of conebeam computed tomography in dental practice. J Can Dent Assoc 2006; 72: 75-80.

20. https://imagej.nih.gov/ij/download.html.

21. White SC, Rudolph DJ. Alterations of the trabecular pattern of the jaws in patients with osteoporosis. Oral Surg Oral Med Oral Pathol Oral Radiol Endod 1999; 88: 628-35.

22. Tabeling HJ, Dolwick MF. Rheumatoid arthritis: diagnosis and treatment. Fla Dent J 1985; 56: 16-8.

23. Deal C. Bone loss in rheumatoid arthritis: systemic, periarticular, and focal. Curr Rheumatol Rep 2012; 14: 231-7.

24. Oliveira ML, Pedrosa EF, Cruz AD, Haiter-Neto F, Paula FJ, Watanabe PC. Relationship between bone mineral density and trabecular bone pattern in postmenopausal osteoporotic Brazilian women. Clin Oral İnvestig 2013; 17: 1847-53.

25. Demirbas AK, Ergun S, Guneri P, Aktener BO, Boyacioglu H. Mandibular bone changes in sickle cell anemia: fractal analysis. Oral Surg Oral Med Oral Pathol Oral Radiol Endod 2008; 106: e41-8.

26. Kavitha MS, An SY, An CH, Huh KH, Yi WJ, Heo MS, et al. Texture analysis of mandibular cortical bone on digital dental panoramic radiographs for the diagnosis of osteoporosis in Korean women. Oral Surg Oral Med Oral Pathol Oral Radiol 2015; 119: 346-56.

27. Alman AC, Johnson LR, Calverley DC, Grunwald GK, Lezotte DC, Hokanson JE. Diagnostic capabilities of fractal dimension and mandibular cortical width to identify men and women with decreased bone mineral density. Osteoporos Int 2012; 23: 16316.

28. Wilding RJ, Slabbert JC, Kathree H, Owen CP, Crombie K, Delport $P$. The use of fractal analysis to reveal remodelling in human alveolar bone following the placement of dental implants. Arch Oral Biol 1995; 40: 61-72.

29. Sansare K, Singh D, Karjodkar F. Changes in the fractal dimension on pre-and post-implant panoramic radiographs. Oral Radiol 2012; 28: 15-23.

30. Zeytinoglu M, Ilhan B, Dundar N, Boyacioglu H. Fractal analysis for the assessment of trabecular peri-implant alveolar bone using panoramic radiographs. Clin Oral Investig 2015; 19: 51924.

31. Updike SX, Nowzari H. Fractal analysis of dental radiographs to detect periodontitis-induced trabecular changes. J Periodontal Res. 2008; 43: 658-64.

32. Ruttimann UE, Webber RL, Hazelrig JB. Fractal dimension from radiographs of peridental alveolar bone. A possible diagnostic indicator of osteoporosis. Oral Surg Oral Med Oral Pathol 1992; 74: 98-110.

33. Doyle MD, Harold R, Suri Js. fractal analysis as a means for the quantification of intramandibular trabecular bone loss from dental radiographs. Proceeding on SPIE 1991; 1380: 227-35.

34. Bozic M, Ihan Hren N. Osteoporosis and mandibles. Dentomaxillofac Radiol. 2006; 35: 178-84.

35. Wick MC, Klauser AS. Radiological differential diagnosis of rheumatoid arthritis. Radiologe 2012; 52: 116-23.

36. Panmekiate $\mathrm{S}$, Ngonphloy $\mathrm{N}$, Charoenkarn T, Faruangsaeng $\mathrm{T}$, Pauwels R. Comparison of mandibular bone microarchitecture between micro-CT and CBCT images. Dentomaxillofac Radiol 2015; 44: 20140322.

37. Van Dessel J, Huang Y, Depypere M, Rubira-Bullen I, Maes F, Jacobs R. A comparative evaluation of cone beam CT and microCT on trabecular bone structures in the human mandible. Dentomaxillofac Radiol 2013; 42: 20130145.

38. Parsa A, Ibrahim N, Hassan B, van der Stelt P, Wismeijer D. Bone quality evaluation at dental implant site using multislice $\mathrm{CT}$, micro-CT, and cone beam CT. Clin Oral Implants Res 2015; 26: e1-7.

39. Ibrahim N, Parsa A, Hassan B, van der Stelt P, Aartman IH, Wismeijer D. Accuracy of trabecular bone microstructural measurement at planned dental implant sites using cone-beam CT datasets. Clin Oral Implants Res 2014; 25: 941-5.

40. Hsu JT, Wang SP, Huang HL, Chen YJ, Wu J, Tsai MT. The assessment of trabecular bone parameters and cortical bone strength: a comparison of micro-CT and dental cone-beam CT. J Biomech 2013; 46: 2611-8.

41. Gonzalez-Martin O, Lee EA, Veltri M. CBCT fractal dimension changes at the apex of immediate implants placed using undersized drilling. Clin Oral Implants Res 2012; 23: 954-7. 